\title{
Availability of iron and major nutrients for phytoplankton in the northeast Atlantic Ocean
}

\author{
Stéphane Blain \\ Laboratoire d'Océanographie et de Biogéochimie, Parc Scientifique et Technologique de Luminy. Case 901, F-13288 \\ Marseille Cedex 09, France \\ Cécile Guieu and Hervé Claustre \\ LOV-CNRS FRE 2317, Observatoire Océanologique de Villefranche-sur-Mer. B.P. 08, 06238 Villefranche-sur-mer, France
}

Karine Leblanc, Thierry Moutin, and Bernard Quéguiner

Laboratoire d'Océanographie et de Biogéochimie, Parc Scientifique et Technologique de Luminy. Case 901, F-13288

Marseille Cedex 09, France

Joséphine Ras

LOV-CNRS FRE 2317, Observatoire Océanologique de Villefranche-sur-Mer. B.P. 08, 06238 Villefranche-sur-mer, France

\section{Géraldine Sarthou}

LEMAR UMR CNRS 6539, Place Nicolas Copernic. 29280 Plouzané, France

\begin{abstract}
Because of recent findings that $\mathrm{Fe}$ is a limiting factor for phytoplankton activity even at relatively high dissolved iron (DFe) concentrations, the potential importance of Fe limitation was revisited in the northeast Atlantic Ocean $\left(39-45^{\circ} \mathrm{N}, 17-21^{\circ} \mathrm{W}\right)$. We report data gathered during deck incubation experiments performed at three stations in February-March 2001 with surface seawater containing DFe concentrations of $\sim 0.40 \mathrm{nmol} \mathrm{L}^{-1}$. At all stations, Fe addition enhanced phytoplankton growth. Fe limitation was moderate and occurred simultaneously with limitation by major nutrients. This was clearly demonstrated for diatoms that were colimited by orthosilicic acid. Micro-, nano-, and picoplankton benefited from Fe enrichment. Experiments performed with the trihydroxamate siderophore desferrioxamine mesylate B (DFOB) indicated that Fe reserves exist within the cells, especially within the larger cells. This reserve could result from luxurious storage of Fe by colimited cells during episodic atmospheric deposition of Saharan dust. Simulating concentrations of dust resulting from aerosol deposition in well-stratified surface waters, we determined that the solubility of Saharan dust was very low $(<0.1 \% \mathrm{w} / \mathrm{w})$ but the amount of $\mathrm{DFe}$ released in seawater was sufficient to relieve the Fe limitation of the ambient phytoplankton community.
\end{abstract}

During the last decade, most biogeochemical studies dedicated to Fe limitation of phytoplankton growth have been carried out in regions characterized by low dissolved iron (DFe) concentrations, such as the equatorial Pacific Ocean (Coale et al. 1996) or the Southern Ocean (de Baar et al. 1995; Boyd et al. 2000; Blain et al. 2001). Recent studies in the Californian coastal upwelling (Hutchins et al. 1998) and the Mediterranean Sea (Sarthou and Jeandel 2001) have shown that even in regions with DFe concentrations one or two orders of magnitude higher than in offshore high-nutrient-low-chlorophyll (HNLC) areas, Fe could be an important factor controlling phytoplankton growth, phytoplankton community structure, and nutrient drawdown. In light of these new findings, the case of the North Atlantic must be revisited.

\section{Acknowledgments}

We thank the captain and the crew of the RV Atalante for excellent technical assistance. The final version benefited from the useful comments of one anonymous reviewer and M. Öztürk. This work was supported by the CNRS. This is contribution $\mathrm{N}^{\circ} 917$ of the IUEM, European Institute for Marine Studies (Brest, France).
Because of the assumption that North Atlantic waters contain high $\mathrm{Fe}$ concentrations, there have been few studies investigating the importance of $\mathrm{Fe}$ on primary production in these waters. The large, shallow continental shelf could be a source of $\mathrm{Fe}$ for the North Atlantic at high latitude. However, during the North Atlantic Bloom Experiment (NABE) Martin et al. (1993) observed low DFe concentrations $(\sim 0.1$ nmol L $\left.{ }^{-1}\right)$ in surface waters at $47^{\circ} \mathrm{N}, 20^{\circ} \mathrm{W}$. Higher DFe values were reported at southerly stations $\left(40^{\circ} \mathrm{N}, 23^{\circ} \mathrm{W}\right)$, ranging from 0.6 to $1.5 \mathrm{nmol} \mathrm{L}^{-1}$ (de Jong et al. 2000), but no bioassay experiments were associated with these measurements. At midlatitudes, large Saharan dust events are also a source of Fe for surface waters of the Atlantic Ocean, with possible implications on biological productivity. For example, a large Trichodesmium bloom following a Saharan dust event was monitored in offshore waters of the West Florida shelf (Lenes et al. 2001). DFe concentrations in surface waters of the North Atlantic are thus expected to be highly variable in space and time, due to the interplay of episodic deposition of Saharan dust, hydrographic features, such as fronts or mesoscales eddies, and biological activities. 


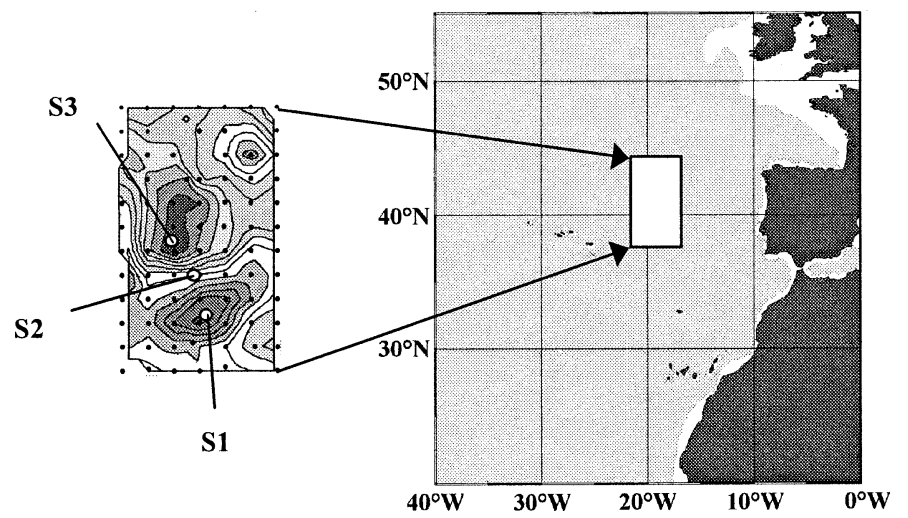

Fig. 1. Location of the area investigated during the cruise POMME1. Left panel shows the positions of Sta. 1 (S1), 2 (S2), and 3 (S3). S1 is in the core of an anticyclonic eddy, S3 in the core of a cyclonic eddy, and S2 at the front between both eddies. The eddies are identified by gradients in geopotential anomalies $(50 \mathrm{db} / 2,000$ db) (in gray).

We report here results from experiments carried out at the boundary between eutrophic and oligotrophic waters of the northeast Atlantic Ocean investigating the importance of $\mathrm{Fe}$ and other major nutrients for phytoplankton growth. Fe availability and the role of dust as a potential source of $\mathrm{Fe}$ for the northeast Atlantic Ocean are also discussed.

\section{Material and methods}

Location of the cruise-The cruise took place in February-March 2001 as part of the French Programme Océanographique Multi-disciplinaire Méso-échelle (POMME). The study area was characterized by high mesoscale physical activity, as demonstrated by the geopotential anomalies measured at $200 \mathrm{~m}$ (L. Prieur pers. comm.) (Fig. 1). Sta. 1 and 3 were located in the core of an anticyclonic and a cyclonic eddy, respectively. Sta. 2 was located at the front between both eddies (Table 1).
Table 1. Location of study sites and respective hydrological features.

\begin{tabular}{lccc}
\hline \hline $\begin{array}{c}\text { Type of } \\
\text { hydrological } \\
\text { structure }\end{array}$ & $\begin{array}{c}\text { Station 1 } \\
\text { anticyclonic } \\
\text { eddy }\end{array}$ & $\begin{array}{c}\text { Station 2 } \\
\text { front }\end{array}$ & $\begin{array}{c}\text { Station 3 } \\
\text { cyclonic } \\
\text { eddy }\end{array}$ \\
\hline Latitude & $40.05^{\circ} \mathrm{N}$ & $40.50^{\circ} \mathrm{N}$ & $41.81^{\circ} \mathrm{N}$ \\
Longitude & $18.45^{\circ} \mathrm{W}$ & $19.03^{\circ} \mathrm{W}$ & $19.36^{\circ} \mathrm{W}$ \\
\hline
\end{tabular}

Sampling and analysis-Water samples were collected with acid-cleaned polyethylene tubes using an Osmonics solid Teflon diaphragm pump. The tubing inlet was lowered using a Kevlar line. Seawater was filtered under laminar flow hoods (class 100) in a clean laboratory van, through a Sartrobran-P-capsule (Sartorius) containing a $0.45-\mu \mathrm{m}$ prefilter and a $0.2-\mu \mathrm{m}$ final filter. The samples were acidified with $\mathrm{HCl}$ supra pur $(\mathrm{MERCK})$ at $\mathrm{pH}<2$ and stored for 3-5 months in the dark at room temperature until analyzed. DFe concentrations were measured on shore in a clean room using flow-injection analysis with chemiluminescence detection. The mean detection limit was $20 \mathrm{pmol} \mathrm{L}^{-1}$ and the mean blank was $30 \mathrm{pmol} \mathrm{L}^{-1}$ (Laes et al. 2003).

In situ concentrations of $\mathrm{NO}_{3}^{-}$and $\mathrm{NO}_{2}^{-}$were analyzed aboard (Fernandez pers. comm.). Concentrations of $\mathrm{Si}(\mathrm{OH})_{4}$ were measured in the laboratory in $0.2-\mu \mathrm{m}$-filtered seawater poisoned with $\mathrm{HgCl}_{2}$ (Strickland and Parson 1972).

Incubation experiments-At Sta. 1 and 3, unfiltered clean seawater from the mixed layer at $25-\mathrm{m}$ depth was pumped and transferred to 4-liter polycarbonate bottles inside the clean laboratory and immediately amended with nutrients and desferrioxamine mesylate $\mathrm{B}$ (DFOB), as described in Table 2. The bottles were capped, sealed with polyvinyl chloride tape, and incubated for up to $5 \mathrm{~d}$ in polyethylene tanks located on deck. The incubators shaded the bottles to $50 \%$ of incident irradiance for photosynthetically active radiation. The dose received varied between 2 and $6 \mathrm{MJ} \mathrm{m}^{-2}$ $\mathrm{d}^{-1}$ during the cruise. A running seawater system supplied continuous water from the sea surface. For each experimen-

Table 2. Description of the different nutrient amendments during the incubation experiments. NPSi represents the simultaneous addition of the major nutrients, resulting in a final concentration in the incubation bottles of $\left.\left[\mathrm{NO}_{3}^{-}\right]=10 \mu \mathrm{mol} \mathrm{L}^{-1},\left[\mathrm{Si}_{(\mathrm{OH}}\right)\right]=2 \mu \mathrm{mol} \mathrm{L}-1$, $\left[\mathrm{PO}_{4}^{3-}\right]=0.31 \mu \mathrm{mol} \mathrm{L}-1$. DFOB is desferrioxamine B.

\begin{tabular}{|c|c|c|c|}
\hline & Station 1 & Station 2 & Station 3 \\
\hline $\begin{array}{c}\text { Aim of the incubation } \\
\text { experiment }\end{array}$ & $\begin{array}{l}\text { Identification of the } \\
\text { limiting factors }\end{array}$ & $\begin{array}{c}\text { Iron } \\
\text { availability }\end{array}$ & $\begin{array}{l}\text { Identificaion of } \\
\text { the limiting factors }\end{array}$ \\
\hline \multirow{6}{*}{ Additions } & Control & $\begin{array}{l}\text { Control } \\
\quad+\text { NPSi }\end{array}$ & Control \\
\hline & + DFe $2.5 \mathrm{nmol} \mathrm{L}-1$ & $\begin{array}{l}+ \text { DFe } 0.7 \mathrm{nmol} \mathrm{L}^{-1} \\
+\mathrm{NPSi}\end{array}$ & + DFe $2.5 \mathrm{nmol} \mathrm{L}-1$ \\
\hline & + DFOB $2.5 \mathrm{nmol} \mathrm{L}^{-1}$ & $\begin{array}{l}+\mathrm{DFe} 2.5 \mathrm{nmol} \mathrm{L}^{-1} \\
+\mathrm{NPSi}\end{array}$ & + DFOB $2.5 \mathrm{nmol} \mathrm{L}^{-1}$ \\
\hline & $\begin{array}{l}+ \text { DFe } 2.5 \mathrm{nmol} \mathrm{L}^{-1} \\
+ \text { NPSi }\end{array}$ & $\begin{array}{l}+ \text { DFOB } 1 \mathrm{nmol} \mathrm{L}^{-1} \\
+ \text { NPSi }\end{array}$ & $\begin{array}{l}+ \text { DFe } 2.5 \mathrm{nmol} \mathrm{L}^{-1} \\
+ \text { NPSi }\end{array}$ \\
\hline & $+\mathrm{NPSi}$ & $\begin{array}{l}+ \text { DFOB } 10 \mathrm{nmol} \mathrm{L}^{-1} \\
+ \text { NPSi }\end{array}$ & $+\mathrm{NPSi}$ \\
\hline & & & + Saharan dust \\
\hline
\end{tabular}


tal treatment, duplicate 4-liter bottles were sacrificed at selected (three) time points during the course of the experiment and subsamples for the following measurements were taken: concentrations of $\mathrm{DFe}, \mathrm{NO}_{3}^{-}$, and $\mathrm{NO}_{2}^{-}\left(\mathrm{NO}_{x}\right), \mathrm{Si}(\mathrm{OH})_{4}$, chlorophyll $a(\mathrm{Chl} a)$, and carotenoids, particulate organic carbon (POC), and particulate organic nitrogen (PON), biogenic silica (BSi), primary production, and rate of silicon uptake. All chemical analyses were done on land. For $\mathrm{NO}_{\mathrm{x}}$ analyses, 0.2$\mu \mathrm{m}$-filtered seawater was kept frozen. Concentrations of $\mathrm{NO}_{x}$ were measured using a Technicon autoanalyzer. Silicic acid was analyzed in $0.2-\mu \mathrm{m}$-filtered seawater poisoned with $\mathrm{HgCl}_{2}$. Particulate organic carbon (POC) and particulate organic nitrogen (PON) were measured using carbon, hydrogen, nitrogen $(\mathrm{CHN})$ analyses on $\mathrm{GF} / \mathrm{F}$-filtered samples. Biogenic silica $(\mathrm{BSi})$ was measured on $0.6-\mu \mathrm{m}$ polycarbonate filters. Concentrations of pigments were measured using high-performance liquid chromatography, using a slight modification of the method proposed by Vidussi et al. (1996). Pigment data were regrouped into pigment indices roughly representing the phytoplankton size classes (pico-, nano-, microphytoplankton) according to the procedure of Vidussi et al. (2001). Carbon uptake rates were measured using radiolabeled $\mathrm{NaH}^{14} \mathrm{CO}_{3}$. Silicon uptake rates were measured using radiolabeled ${ }^{32} \mathrm{Si}(\mathrm{OH})_{4}$ (Leblanc et al. 2002). Incubations for $\mathrm{C}$ and $\mathrm{Si}$ uptake rates were done on deck for $24 \mathrm{~h}$ starting at sunrise.

At Sta. 3, Saharan dust was also added to incubation bottles to determine its potential as an Fe source for phytoplankton growth (Table 2). The dust we used was composed of fine fractions of surface soils collected in the Hoggar region (southern Algeria) with grain-size distribution and chemical composition typical for Saharan aerosols collected far from the source (Guieu et al. 2002a). The final concentration in the incubation bottles was $1.34 \pm 0.08 \mathrm{mg} \mathrm{L}^{-1}$. In the course of this experiment, 60-ml subsamples were taken and filtered through $0.2-\mu \mathrm{m}$ filters using a clean plastic syringe. The filtrate was acidified, stored, and analyzed for DFe as described above.

At Sta. 2, various amounts of DFe and DFOB were added to 20-liter polycarbonate bottles (Table 2) and incubated as described above. Major nutrients were added to all bottles at the same concentration as given in Table 2. Subsamples were taken at different times during the incubation to determine the chemical and biological parameters described above. All handling of the 20-liter bottles during subsampling was done inside the clean van.

\section{Results}

Characteristics of the surface waters-Vertical profiles of sigma theta, $\mathrm{DFe}$, and $\mathrm{NO}_{\mathrm{x}}$ at the three stations are shown in Figure 2. At Sta. 1, concentrations of $\mathrm{NO}_{\mathrm{x}}$ were homogenous $\left(3.47 \mu \mathrm{mol} \mathrm{L}{ }^{-1}\right)$ in the upper $60 \mathrm{~m}$ of the water column. DFe was not measured throughout the water column at this station. The DFe concentration $\left(0.45 \mathrm{nmol} \mathrm{L} \mathrm{L}^{-1}\right)$ is given for the depth where water for the incubation experiments was sampled. At Sta. 2, concentrations of DFe increased slightly with depth following the small increase in sigma theta. Concentrations of $\mathrm{NO}_{x}$ were nearly constant in the first $60 \mathrm{~m}$ of the water column. At Sta. 3, concentrations of $\mathrm{DFe}$ and $\mathrm{NO}_{\mathrm{x}}$ in the upper $60 \mathrm{~m}$ of water column varied between 0.22 and $0.45 \mathrm{nmol} \mathrm{L^{-1 }}$ and 5.51 and $5.86 \mathrm{nmol}$ $\mathrm{L}^{-1}$, respectively. Variations with depth were similar for both chemical species, revealing a small increase of concentrations between 20 and $30 \mathrm{~m}$, consistent with a small gradient in sigma theta at the same depth.

Initial concentrations of $\mathrm{DFe}$ at $25 \mathrm{~m}$ were similar at the three study sites $\left(0.45,0.41\right.$, and $0.40 \mathrm{nmol} \mathrm{L}^{-1}$ at Sta. 1, 2, and 3 , respectively) (Table 3 ). Concentrations of $\mathrm{NO}_{\mathrm{x}}$, $\mathrm{Si}(\mathrm{OH})_{4}, \mathrm{Chl} a$, and BSi increased substantially along a south to north gradient (Table 3). At all sites, the phytoplankton community was dominated by nanophytoplankton (53-59\%, Table 3) and picophytoplankton (31-34\%, Table 3) and the contribution of microphytoplankton to total phytoplankton biomass was relatively small $(<15 \%$, Table 3$)$.

Identification of the limiting factors at Sta. 1 and 3Addition of DFe alone or in combination with NPSi had a pronounced effect on phytoplankton biomass production during the 5-d incubation at Sta. 1 and 3 (Fig. 3). At Sta. 1, the final Chl $a$ concentration was 1.6- and 2-fold higher in the $\mathrm{DFe}$ and $\mathrm{DFe}+\mathrm{NPSi}$ treatments, respectively, as compared with the unamended control (Fig. 3A). At Sta. 3, addition of DFe and DFe+NPSi resulted in a final Chl $a$ concentration of 1.4- and 1.5-fold higher, respectively, as compared with the unamended control (Fig. 3B). In contrast, addition of NPSi alone did not stimulate phytoplankton biomass production as compared with the unamended control at the two stations. A minor increase in phytoplankton biomass during the 5-d incubation was observed in the DFOBamended treatments at Sta. 1 and 3.

Dissolved Fe and DFe+NPSi addition also affected all other biological parameters determined in the present study (Fig. 4). At Sta. 1, the stimulation by DFe and DFe+NPSi was more pronounced for Chl $a$ and POC integrated over the 5-d incubation (Fig. 4A,B) than for PON and BSi (Fig. $4 \mathrm{D}, \mathrm{E})$. Primary production and the silicon uptake rate integrated over the 5-d incubation were particularly enhanced upon addition of DFe +NPSi (both by a factor of four) (Fig. 4C,F). At Sta. 3, DFe addition alone stimulated uptake rates of silicon (Fig. 4F). However, the addition of DFe in combination with NPSi or the addition of dust resulted in elevated concentrations of $\mathrm{Chl} a$, POC, PON, and BSi integrated over the 5-d incubation as compared with the control treatment (Fig. 4A,B,D,E). Similar to Sta. 1, particularly the primary production and the silicon uptake rate integrated over the 5-d incubation were stimulated by the addition of DFe + NPSi (by factors of 1.9 and 3.6, respectively) (Fig. 4C,F).

Pigment analysis was used to determine the contribution of different phytoplankton size classes responding to nutrient amendment at Sta. 1 and 3 (Fig. 5). Microphytoplankton (mainly diatoms) revealed the most pronounced response to DFe addition, resulting in a 17 - and 10-fold increase in Chl $a$ in the course of the 5-d incubation at Sta. 1 and 3, respectively (Fig. 5A,D). Addition of dust resulted in a similar increase in Chl $a$ at Sta. 3 (Fig. 5D). However, Chl $a$ concentrations increased most in this size class in the course of the 5-d incubation when DFe+NPSi was added (by factors 

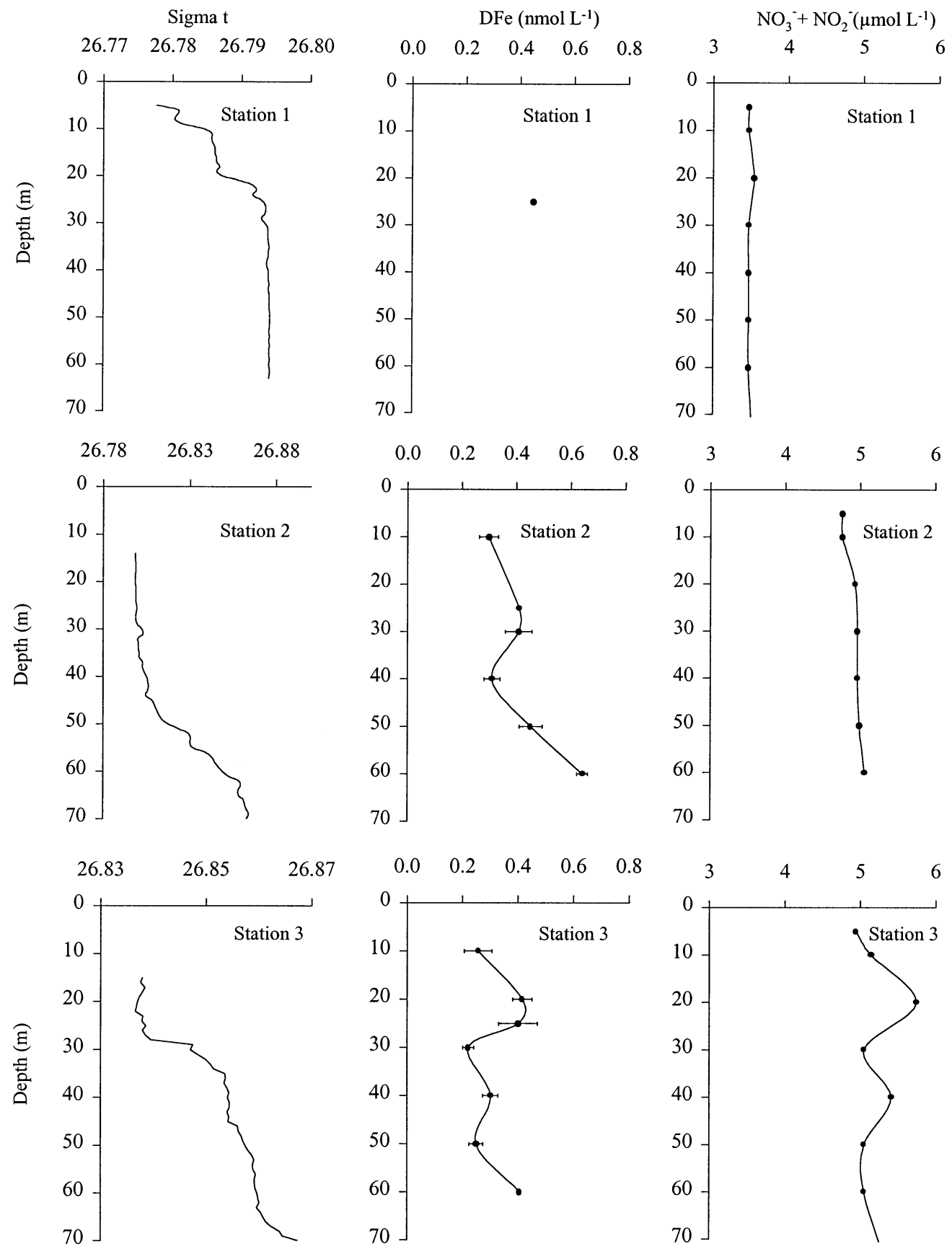

Fig. 2. Depth profiles of sigma theta and concentrations of $\mathrm{DFe}$ and $\mathrm{NO}_{\mathrm{x}}$ at Sta. 1, 2, and 3. At Sta. 1, the DFe concentration is given only for the depth where the water for the incubation experiment was sampled.

of 40 and 11 at Sta. 1 and 3, respectively) (Fig. 5A,D). For comparison, in the control treatments, concentrations of $\mathrm{Chl}$ $a$ increased 6- and 3.5-fold at Sta. 1 and 3, respectively, during the 5-d incubation. At Sta. 1, nano- and picophytoplankton were stimulated by the addition of DFe and DFe+NPSi (Fig. 5B,C). In contrast, no differences in Chl $a$ concentrations among treatments were observed for nanoand picophytoplankton at Sta. 3 (Fig. 5E,F). Concentrations of Chl $a$ in the picophytoplankton size class decreased in all treatments after 83 and $58 \mathrm{~h}$ at Sta. 1 and 3, respectively
(Fig. 5C,F). Addition of DFOB inhibited significant phytoplankton growth in all size classes (Fig. 5).

Iron availability at Sta. 2-The growth rate of the phytoplankton community and of the different phytoplankton size classes was calculated using the increase in Chl $a$, POC, and PON between $t=60 \mathrm{~h}$ and $t=96 \mathrm{~h}$ (Table 4). We assume that, during this period, cells were growing exponentially (the different treatments are summarized in Table 2 ). The growth rate of the phytoplankton community, in the 
Table 3. Initial chemical and biological properties of the surface seawater used for the incubation experiments.

\begin{tabular}{|c|c|c|c|}
\hline & Station 1 & Station 2 & Station 3 \\
\hline Dissolved iron $\left(\mathrm{nmol} \mathrm{L}^{-1}\right)$ & 0.45 & 0.41 & 0.40 \\
\hline Nitrate + nitrite $\left(\mu \mathrm{mol} \mathrm{L}{ }^{-1}\right)$ & 3.65 & 4.96 & 5.59 \\
\hline Phosphate $(\mu \mathrm{mol} \mathrm{L}-1)$ & 0.21 & 0.32 & 0.17 \\
\hline Silicic acid $\left(\mu \mathrm{mol} \mathrm{L}^{-1}\right)$ & 1.81 & 1.90 & 2.21 \\
\hline Chlorophyll $a\left(\mu \mathrm{g} \mathrm{L}^{-1}\right)$ & 0.24 & 0.58 & 0.81 \\
\hline Biogenic silica $(\mu \mathrm{mol} \mathrm{L}-1)$ & 0.046 & 0.050 & 0.103 \\
\hline \% Chl a microphytoplankton & 8 & 10 & 15 \\
\hline$\%$ Chl $a$ nanophytoplankton & 57 & 59 & 53 \\
\hline \% Chl $a$ picophytoplankton & 34 & 31 & 32 \\
\hline
\end{tabular}

control, based on the increase in Chl $a\left(0.38 \mathrm{~d}^{-1}\right)$ was higher than the estimates based on the increases of PON and POC, 0.22 and $0.19 \mathrm{~d}^{-1}$, respectively (Table 4). DFOB addition, 1 or $10 \mathrm{nmol} \mathrm{L}^{-1}$, reduced the growth rate by a factor of two. Iron addition at 0.7 or $2.5 \mathrm{nmol} \mathrm{\textrm {L } ^ { - 1 }}$ resulted in the maximal growth rate of the whole phytoplankton community $(0.57$ $\left.\mathrm{d}^{-1}\right)$. In the control treatment, the growth rate of microphytoplankton was 1.6- and 2.4-fold higher than the growth rate of nanophytoplankton and picophytoplankton, respectively. DFOB additions had a relatively low impact on the growth rate of microphytoplankton but precluded growth of picophytoplankton. An intermediary effect was observed on nanophytoplankton. DFe addition stimulated the growth rate of the three phytoplankton groups in the same manner by a factor of 1.5 .

\section{Discussion}

Ambient iron concentrations - The concentrations of DFe measured at the different stations were intermediate values compared with concentrations reported in the literature in the northeast Atlantic. The lowest concentrations (0.07-0.2 nmol L ${ }^{-1}$ ) have been observed at $47^{\circ} \mathrm{N}, 20^{\circ} \mathrm{W}$ (Martin et al. 1993). At $40^{\circ} \mathrm{N}, 23^{\circ} \mathrm{W}$, an area closer to our study sites, concentrations of $0.8-1.5 \mathrm{nmol} \mathrm{L}^{-1}$ have been reported (de Jong et al. 2000). It is difficult to firmly interpret these differences, but variability on short spatial and temporal scales is not surprising in this area. This region of the northeast Atlantic is characterized by permanent frontal structures that are likely responsible for the variability in the chemical and biological properties of surface seawater. The mesoscale features occurring in the studied area (Fig. 1) could also impact the spatial and temporal distribution of Fe. Most anticyclonic eddies are generated along the continental shelf of Portugal and then advected westward. Therefore, Fe could be transported from the Fe-rich shelf zone offshore. Eddies have a relatively long life time (several months), but the water at the periphery can rapidly mix with the surrounding water. This might provide a mechanism explaining the relatively high DFe concentrations in this area. Atmospheric deposition could be another source of $\mathrm{Fe}$. Massive airborne plumes of desert dust from the Sahara are exported to the north Atlantic Ocean (Moulin et al. 1997). Under particular conditions, mineral aerosol deposition leads to a significant increase in the concentration of DFe in surface waters. This

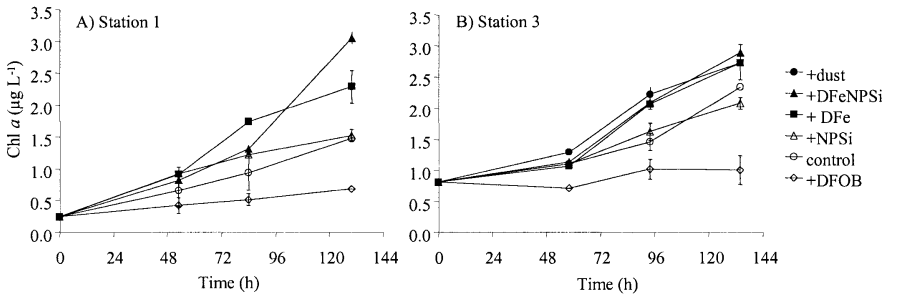

Fig. 3. Concentrations of Chl $a$ in unamended and nutrientamended treatments in the course of the incubations at (A) Sta. 1 and (B) Sta. 3. The error bars represent the standard deviation from duplicate incubations.

has clearly been demonstrated in the well-stratified Mediterranean surface waters (Guieu et al. 2002a). Even if the stratification in the northeast Atlantic surface waters is weaker than in the Mediterranean Sea, atmospheric dust deposition may episodically and locally increase the Fe concentration in surface waters (Lenes et al. 2001). Both factors, hydrodynamic and atmospheric deposition, might explain the heterogeneous distribution and the high concentrations of $\mathrm{DFe}$ in surface waters of the northeast Atlantic. In any case, concentrations of $\mathrm{DFe}$ in the northeast Atlantic are one order of magnitude higher than the lowest concentrations measured in Fe-depleted waters of remote HNLC areas.

Iron versus major nutrient availability for phytoplankton growth-The experiments performed in the present study were designed to investigate the chemical factors limiting phytoplankton growth with particular focus on Fe, which has been poorly studied in this area. Nutrient addition experiments have proven to be very useful in identifying potential chemical limitations or simultaneous chemical limitation of phytoplankton. Container artifacts have been mentioned as
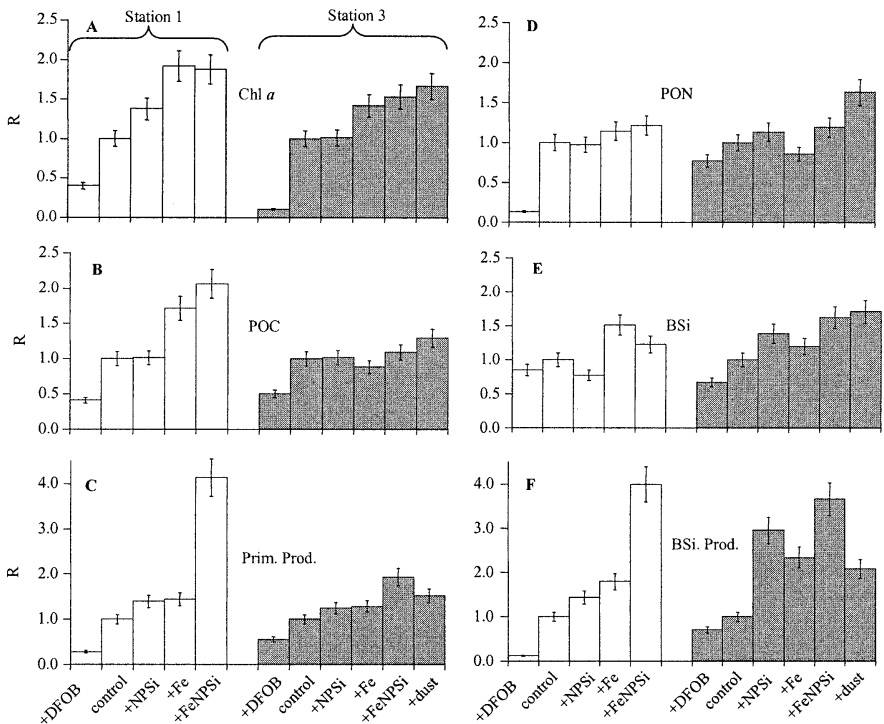

Fig. 4. Integrated value over the incubation period in nutrientamended treatments relative to the control (R) for concentrations of (A) Chl $a$, (B) POC, (C) primary production (Prim. Prod.), (D) PON, (E) BSi, (F) biogenic silica production (BSi Prod.). Note different scales on the $y$-axis. 

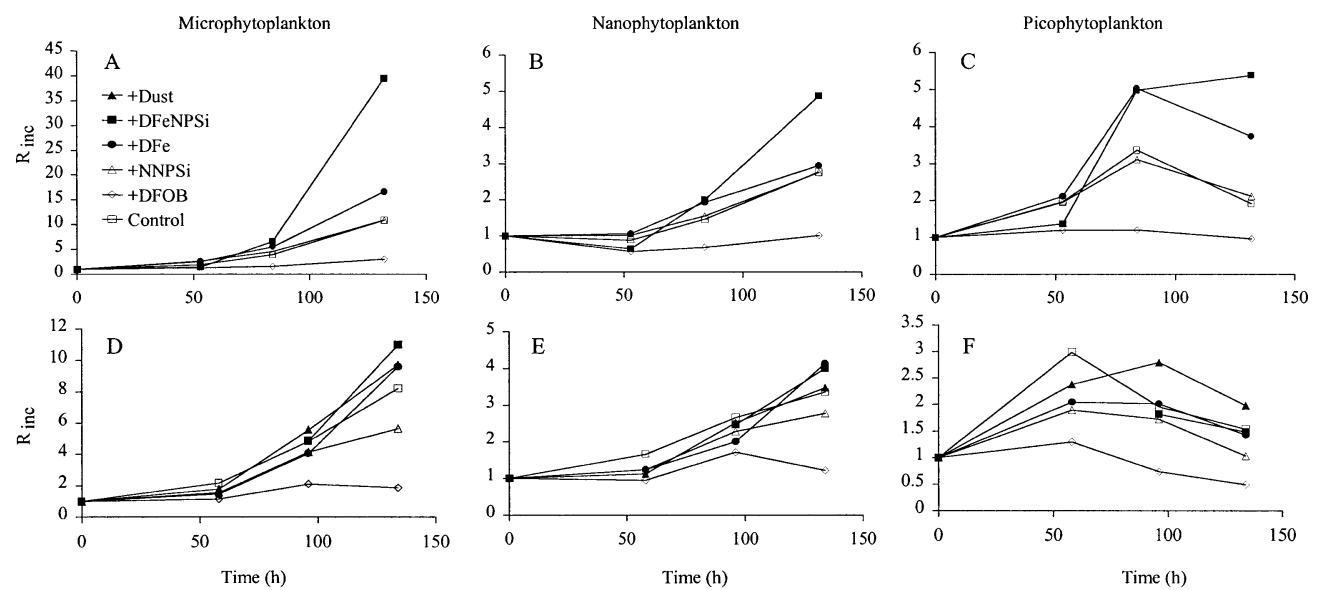

Fig. 5. Relative increase $\left(R_{\text {inc. }}\right)$ in Chl $a$ concentrations in the three different phytoplankton size classes, derived from pigment analysis, in nutrient-amended and unamended treatments in the course of the incubation at Sta. 1 (A-C) and 3 (D-F). All values are normalized to the concentration of $\mathrm{Chl} a$ at the starting time of the incubations.

an important bias of this type of experiment, but a recent comparison of data gathered from both shipboard Fe addition experiments and mesoscale in situ enrichments suggest that shipboard experiments provide a robust indication of the nutritional status of the native algal community (Gall et al. 2001). The concept of the limiting factor according to Liebig's law implies the control of phytoplankton growth by a single factor. However, it is now recognized that the concept of multiple limitations is more realistic. Metabolisms of different chemical elements are interconnected at the cell level, which implies that the growth of an individual cell can be concurrently limited by several factors (Sciandra et al. 1997). As far as the whole phytoplankton community is concerned, simultaneous limitation can result from different limiting factors acting on different contributors of the phytoplankton community.

In all experiments performed in the present study, phytoplankton biomass increased significantly in the control treatments. This observation implies that phytoplankton have the potential to grow in an incubation bottle at a period of the year when no phytoplankton bloom is expected nor was detected. This suggests that light limitation as a consequence of the deep mixed layer and low surface irradiance is the first in situ limiting factor of phytoplankton growth at this time of the year. Incubating phytoplankton at surface irradiance during wintertime has a somewhat similar effect on phytoplankton growth as the onset of stratification. Incubat- ing has thus the advantage of removing the effect of light limitation so that the effect of nutrient limitation can be properly assessed.

In our experiments, phytoplankton growth was always stimulated by the addition of $\mathrm{Fe}$, even though ambient concentrations of DFe were relatively high $(0.40-0.45 \mathrm{nmol}$ $\left.\mathrm{L}^{-1}\right)$. Fe limitation is not a step function with two extreme states: Fe limited versus Fe replete. There is evidence that a continuum in the degree of Fe limitation exists. Along the Californian coast, a complex mosaic of different types of water masses was described using a four-level model. The systems were classified as Fe replete and slightly, moderately, and highly limited, with different impacts on the $\mathrm{Si}(\mathrm{OH})_{4} /$ $\mathrm{NO}_{3}^{-}$drawdown and on the biological communities (Hutchins et al. 1998). A positive response to $\mathrm{Fe}$ addition in seawater with ambient concentrations of DFe of a few hundred picomoles has already been observed, for example, in the sub-Antarctic region of the Southern Ocean (Sedwick et al. 2002). This is similar to the observations made in the present study.

Sta. 1 and 3: evidence of multiple chemical limitationsAt Sta. 1, our results clearly show that the response of the phytoplankton community to the addition of limiting nutrients was more important (roughly twofold) for uptake processes than for biomass accumulation. The large response of the primary production was only obtained when both $\mathrm{Fe}$ and

Table 4. Growth rate $\left(\mathrm{d}^{-1}\right)$ of different phytoplankton size classes and the whole phytoplankton community calculated from increases in Chl $a$, POC, and PON between $t=60 \mathrm{~h}$ and $t=96 \mathrm{~h}$, assuming an exponential growth phase. Data are from Sta. 2.

\begin{tabular}{|c|c|c|c|c|c|c|}
\hline \multirow[b]{2}{*}{ Parameters } & \multicolumn{3}{|c|}{ Phytoplankton size classes } & \multicolumn{3}{|c|}{ Whole phytoplankton community } \\
\hline & Micro Chl $a$ & Nano Chl $a$ & Pico Chl $a$ & Chl $a$ & PON & POC \\
\hline +DFOB $10 \mathrm{nmol} \mathrm{L}-1$ & 0.56 & 0.23 & 0 & 0.19 & 0.15 & 0.06 \\
\hline+ DFOB $1 \mathrm{nmol} \mathrm{L}-1$ & 0.52 & 0.20 & 0 & 0.14 & 0.15 & 0.14 \\
\hline Control & 0.65 & 0.41 & 0.27 & 0.38 & 0.22 & 0.19 \\
\hline$+\mathrm{DFe} 0.7 \mathrm{nmol} \mathrm{L}{ }^{-1}$ & 1.03 & 0.62 & 0.33 & 0.57 & 0.32 & $(0.12)$ \\
\hline+ DFe $2.5 \mathrm{nmol} \mathrm{L}^{-1}$ & 0.98 & 0.70 & 0.39 & 0.56 & 0.29 & 0.35 \\
\hline$\mu_{\text {cont }} / \mu_{\max }(\%)$ & 67 & 68 & 69 & 67 & 72 & 54 \\
\hline
\end{tabular}


major nutrients were added. Pigment analysis indicated that all three phytoplankton size classes were stimulated by the addition of DFeNPSi, but the effect on microphytoplankton was most pronounced (Fig. 5). At the end of the incubations, the ratios $R=R_{\text {inc. }}$ ( $\left.+\mathrm{DFeNPSi}\right) / R_{\text {inc. }}(\mathrm{DFe})$ were $2.4,1.7$, and 1.5 for micro-, nano-, and picoplankton, respectively. Similarly, when nutrient-amended treatments (+DFeNPSi) are compared with the unamended treatments, the ratio $R=$ $R_{\text {inc. }}(+\mathrm{DFeNPSi}) / R_{\text {inc. }}$ (control) was higher for microphytoplankton (3.6) than for nano- and picophytoplankton (1.8 and 2.5, respectively). This suggests that growth of the phytoplankton community, in particular diatoms, is colimited by several nutrients. Comparing the ambient concentration of $\mathrm{Si}(\mathrm{OH})_{4}$ at Sta. $1\left(1.8 \mu \mathrm{mol} \mathrm{L}{ }^{-1}\right)$ with the half-saturation constant of Si uptake $\left(K_{\mathrm{Si}}=3.5 \mu \mathrm{mol} \mathrm{L}{ }^{-1}\right.$; Leblanc 2002), it is obvious that $\mathrm{Si}$ uptake is severely limited by $\mathrm{Si}(\mathrm{OH})_{4}$ availability (34\% of $V_{\max }$ ). If $\mathrm{Si}$ was the unique limiting factor for diatom growth, the addition of $2 \mu \mathrm{mol} \mathrm{L}{ }^{-1} \mathrm{Si}(\mathrm{OH})_{4}$ would have relieved, at least partly, this limitation. However, this was not observed in the present study. Therefore, phytoplankton growth is likely colimited by $\mathrm{Si}$ and $\mathrm{Fe}$ at this study site. This confirms previous studies that report that $\mathrm{Fe}$ availability can affect $K_{\mathrm{Si}}$ and $V_{\max }$ of Si uptake by diatoms (De La Rocha et al. 2000). It was suggested that either Fe is a cofactor of the transport system or that Fe limits other processes within the cell, which subsequently impact the $\mathrm{Si}$ uptake due to a lack in energy availability. However, in the Californian upwelling region, Firme et al. (2003) observed only small effects of Fe addition on biogenic silica production. This argues against a colimitation of the $\mathrm{Si}$ uptake mechanism by Fe. The type of multiple limitation, co- or simultaneous, is likely dependent on the species of diatoms.

Although DFeNPSi addition relieved the colimitation of Si uptake, BSi concentration did not increase substantially over the incubation period. This resulted in a very high specific growth rate of lightly silicified diatoms. Using pigment data, we estimated a contribution of diatoms to the total Chl $a$ concentration of $42 \%$ at the end of the incubations. Although growing rapidly, diatoms did not fully dominate the phytoplankton community. Hutchins et al. (2002) reported that Fe addition in shipboard incubations with surface waters of the Peru Current resulted in a final composition of the phytoplankton community dominated equally by pennate diatoms and haptophytes. This and the present study contrast with results obtained during Fe-addition experiments in HNLC areas such as the Californian upwelling (Hutchins and Bruland 1998) or the Southern Ocean (Sedwick et al. 2002). Hutchins et al. (2002) suggested that, during the Peru upwelling experiments, Si limitation of diatoms at the end of the incubations precluded the diatoms from dominating the phytoplankton community. This was consistent with the drawdown of $\mathrm{Si}(\mathrm{OH})_{4}$ to $2 \mu \mathrm{mol} \mathrm{L}{ }^{-1}$ at day 4 , which is low enough to limit Si uptake because a $K_{\mathrm{Si}}$ of $2.9 \mu \mathrm{mol} \mathrm{L}{ }^{-1}$ has been measured in this area. In our case, the growth of diatoms did not decrease significantly the concentrations of $\mathrm{Si}(\mathrm{OH})_{4}$ during the course of the incubation. The very low abundance of diatoms at the beginning of the incubations is more likely the explanation of the fact that diatoms were not dominant at the end of the incubation.

The nanophytoplankton size class responded only to the addition of DFeNPSi, indicating also multiple limitation, by Fe and other major nutrients. Si can be excluded as the limiting nutrient because siliceous organisms were not dominating this phytoplankton size class. The biomass reached in the treatment with Fe was similar to that in the treatment with DFeNPSi at $t=84 \mathrm{~h}$. Nanophytoplankton growth decreased in the $\mathrm{Fe}$ treatment after this time point. The initial concentration of nitrate was $3.6 \mu \mathrm{mol} \mathrm{L}^{-1}$ in our experiment. At $t=84 \mathrm{~h}$, there were $1.8 \mu \mathrm{mol} \mathrm{L} \mathrm{L}^{-1}$ and $8 \mu \mathrm{mol} \mathrm{L} \mathrm{L}^{-1}$ of nitrate in the + DFe and + NPSi treatments, respectively. We hypothesize that the treatment $+\mathrm{DFe}$ became $\mathrm{N}$ limited in the last part of the incubation. If true, such an $\mathrm{N}$ limitation could also affect the growth of other phytoplankton groups at the end of the incubations. The picophytoplankton group responded to $\mathrm{Fe}$ addition with or without major nutrients added. This group was also Fe limited. In a general manner, the decline of the biomass after $t=84 \mathrm{~h}$ could be due to grazing because all the treatments were affected.

At Sta. 3, the responses during the incubation experiments were smaller than at Sta. 1, especially for Chl $a$, POC, and primary production for the whole phytoplankton community and for Chl $a$ in the microphytoplankton size class. The initial composition of the phytoplankton community was very similar at these two stations, so it cannot explain the different responses observed during the experiments (Table 1). Nanophytoplankton contributed mainly to overall phytoplankton biomass, and few diatoms were observed. Sta. 1 and 3 also had similar concentrations of DFe, but Sta. 3 had higher concentrations of nitrate and $\mathrm{Si}(\mathrm{OH})_{4}$. Therefore, the difference in the magnitude of the response during the incubation experiment shows that the limitation by the major nutrients at Sta. 3 was weaker than at Sta. 1. At Sta. 3, a significant response of the microphytoplankton to NPSi and DFeNPSi additions was observed. Fe addition led to an increase in BSi similar to that measured at Sta. 1. This is also true for the Si uptake rate. The half-saturation constant $K_{\mathrm{Si}}$ measured at Sta. 3 was $4.1 \mu \mathrm{mol} \mathrm{L}{ }^{-1}$ (Leblanc 2002), allowing the diatoms to take up $\mathrm{Si}(\mathrm{OH})_{4}$ at only $36 \%$ of the maximal uptake rate. Therefore, $\mathrm{Si}$ and Fe likely colimited diatom growth also at Sta. 3.

Our results demonstrate that phytoplankton growth is colimited by $\mathrm{Fe}$ and major nutrients when light limitation is removed. The most pronounced decrease during the 5-d incubation in the control treatment was observed for $\mathrm{NO}_{\mathrm{x}}$ (from $3.7 \mu \mathrm{mol} \mathrm{L}{ }^{-1}$ to $0.95 \mu \mathrm{mol} \mathrm{L}{ }^{-1}$ and from $5.6 \mu \mathrm{mol}$ $\mathrm{L}^{-1}$ to $0.86 \mu \mathrm{mol} \mathrm{L} \mathrm{L}^{-1}$ at Sta. 1 and 3, respectively; data not shown). Based on this observation, we hypothesize that $\mathrm{N}$ becomes the limiting nutrient for phytoplankton growth at higher light intensities. The colimitations existing in early spring are, therefore, likely different from those prevailing at other times of the year.

Iron bioavailability: $\mathrm{DFOB}$ and $\mathrm{Fe}$ addition experiments - Desferrioxamine B (DFOB) is a trihydroxamate siderophore produced by terrestrial bacteria. This molecule has been used to greatly reduce $\mathrm{Fe}$ uptake by the phytoplankton community in seawater (Wells et al. 1994; Hutchins et al. 1999a; Wells 1999). Based on the idea that concentrations of $\mathrm{DFe}$ were relatively high in the northeast Atlantic, we reduced $\mathrm{Fe}$ availability by the addition of DFOB. In our 
experiments, DFOB addition lowered the phytoplankton activity compared with the control treatments. This confirms that the ambient concentrations of DFe were only moderately limiting for the phytoplankton. Even in the bottles with 10 nmol L ${ }^{-1}$ of DFOB, the biomass increased slowly. We discuss hereafter which $\mathrm{Fe}$ pool could be bioavailable for the phytoplankton community in these experiments. In our study, the ratio $[\mathrm{DFOB}] /[\mathrm{DFe}]$ was 22 , thus higher than the ratio of 12.6 used in coastal waters (Hutchins et al. 1999a). In surface Antarctic waters, a ratio between 12 and 25 was also enough to preclude the growth of the small diatom Chatoceros brevis (Timmermans et al. 2001). Based on measurements of natural ligand concentrations and apparent stability constants at a station located $4^{\circ}$ west of our sampling sites (Boyé et al. 2003), we calculated that less than a few picomoles of DFe were still bound to natural $\mathrm{Fe}$ ligands after DFOB addition. This residual DFe, not complexed by DFOB, could not be responsible for the observed growth in our bottles with DFOB additions. The bioavailability of $\mathrm{Fe}$ bound to siderophores has been investigated by several authors. In a general manner, marine heterotrophic bacteria utilize Fe bound to siderophores (Granger and Price 1999). Fe bound to various exogenous siderophores is taken up by $S y$ nechococcus. This has been demonstrated using culture experiments (Hutchins et al. 1999b). Evidence has also been provided by the same investigators that Fe-siderophores are an available source of $\mathrm{Fe}$ for natural populations dominated by heterotrophic bacteria and Synechococcus.

The issue whether Fe-siderophores are available for eukaryotes is still a question of debate. Under Fe-deplete conditions, diatoms are able to acquire $\mathrm{Fe}$ from $\mathrm{Fe}-\mathrm{DFOB}$ or Fe-DFOE complexes (Soria-Dengg and Horstmann 1995). In diatom cultures, Thalassiosira weissflogii and Skeletonema costatum also used siderophore-bound Fe, although they preferred Fe bound to tetrapyrol-type ligands (Hutchins et al. 1999b). Recently, it was pointed out that caution should be exercised in interpreting the results of DFOB-addition experiments because the addition of DFOB might not impose Fe stress uniformly across the biological community (Martinez et al. 2000). Consequently, subpopulations of marine phytoplankton and bacteria might use Fe bound to DFOB. This was also demonstrated under Fe-limited conditions (Granger and Price 1999; Maldonado and Price 1999). Our results showing that growth of some phytoplankton size classes is possible even if DFOB is added could reinforce the previous findings that $\mathrm{Fe}$ bound to DFOB can be taken up by cells. However, if this is true, it is not clear why the largest phytoplankton size class is more efficient than the smallest size class in taking up Fe from FeDFOB. This leads us to examine an alternative hypothesis to explain our experiments: Fe reserves within the cells. At the end of our incubations at Sta. $1(t=5.4 \mathrm{~d})$, primary production in the DFOB bottles was $28 \%$ of the C uptake measured in the control. This compares quite well with previous results of similar experiments (Wells 1999). Based on short-term incubations $(7 \mathrm{~h})$, the authors suggested that minor growth of large cells might be due to the use of an Fe reserve. Luxurious storage of $\mathrm{Fe}$ has been demonstrated (Sunda and Huntsman 1995), but it occurs mainly when cells are growing in an Fe-replete environment. In our case, we have dem- onstrated that large cells are moderately Fe limited. Considering $\mathrm{Fe}$ limitation as a single factor controlling growth, the cells should not have large Fe reserves at the beginning of the experiment. However, as discussed in the previous section, at least the microphytoplankton is in fact colimited by a factor other than $\mathrm{Fe}$; this might favor $\mathrm{Fe}$ storage within the cells, particularly at Sta. 1. It is also possible that the DFOBFe complexes were partly dissociated by sunlight during the incubations (Barbeau et al. 2001). If Fe released by such photodissociation was bioavailable, the large cells, being more Fe limited, could respond more than in other experiments with $\mathrm{Fe}$ additions.

Quantitative information on the bioavailability of $\mathrm{Fe}$ for the phytoplankton community is given by the experiment carried out at Sta. 2. The results summarized in Table 4 show that the addition of $0.7 \mathrm{nmol} \mathrm{L}{ }^{-1} \mathrm{DFe}$ provided enough $\mathrm{Fe}$ to allow the different groups of phytoplankton to grow at their maximum growth rates. Caveats of this approach have been previously discussed (Hutchins et al. 2002); however, useful information on the potential growth rate of the phytoplankton community or groups within the community can be inferred. Based on the net increase in Chl $a$, microphytoplankton, nanophytoplankton, and picophytoplankton growth rates in the control treatment were $2 / 3$ of the maximal growth rate. At first glance, this result can be surprising considering that the magnitude of Fe limitation has often been linked to cell size (Sunda and Huntsman 1997). When the Fe resource is decreasing, smaller cells take advantage due to a higher surface-to-volume ratio to maintain a growth rate close to the maximum, while large cells are already $\mathrm{Fe}$ limited. This results in apparent saturation constants for growth rates that are lower for smaller than for larger cells (Blain et al. 2002; Hutchins et al. 2002). We see in the previous section that DFOB addition impacted growth of the three phytoplankton size classes in different manners, maybe due to the occurrence of $\mathrm{Fe}$ reserves. If the contribution of the Fe reserve to the growth rate of the cells could be removed, the microphytoplankton, which had the largest Fe reserve, would have a lower $\mu / \mu_{\max }$ than the nanophytoplankton. The same argument leads to a lower $\mu / \mu_{\max }$ for nanophytoplankton than for picophytoplankton. Therefore, the results of our experiments are not in conflict with the general view that Fe limitation is dependent on the cell size.

Saharan dust, a potential source of bioavailable ironInput of bioavailable Fe by dust deposition at the surface of the ocean was postulated to explain an increase in the biological pump in the Southern Ocean during the glacial period (Martin 1990). In oligotrophic areas, dust deposition has also been suggested to explain the switch between nitrogen- and phosphorus-limited regimes (Falkowski 1997). However, there is still little direct evidence of the link between dust deposition and an increase in biological productivity in surface waters (Lenes et al. 2001). One of the reasons is that dust deposition is of a highly sporadic nature. The area we investigated during our cruise is affected by Saharan dust outbreaks, although the most prominent areas are found in the tropical North Atlantic Ocean (Moulin et al. 1997). The goal of the experiment we conducted at Sta. 3 was to get insight into the potential role of Saharan dust deposition on 
phytoplankton activity. In our experiment, the amount of dust added in the incubation bottles $\left(1.34 \mathrm{mg} \mathrm{L}^{-1}\right)$ was adjusted to mimic dust concentrations following a large $\mathrm{Sa}$ haran deposition event in a well-stratified surface layer. Addition of Saharan dust stimulated growth of the phytoplankton community in a very similar manner as iron additions did (Figs. 3-5). This demonstrated that Saharan dust is indeed a potential source of bioavailable Fe for phytoplankton. Considering that the Saharan dust used in the experiment is characterized by a total concentrations of $\mathrm{Fe}$ of $5 \%(\mathrm{w} / \mathrm{w})$ (Guieu et al. 2002b), the total amount of particulate Fe added to the bottle was $0.25 \mathrm{mg}$. Most of the dissolution occurred within the first $58 \mathrm{~h}$. We calculated that the average amount of $\mathrm{Fe}$ resulting from the dissolution of dust was $\sim 0.6 \mathrm{nmol} \mathrm{L}{ }^{-1}$. From production of POC during the incubation $\left(0.04 \mathrm{mmol} \mathrm{L}^{-1}\right)$ and a ratio $\mathrm{Fe} / \mathrm{POC}=1 \times$ $10^{-5} \mathrm{~mol} \mathrm{~mol}^{-1}$, the amount of Fe taken up by phytoplankton was estimated to be less than $0.04 \mathrm{nmol} \mathrm{L}^{-1}$ and did not affect significantly the concentration of DFe. Thus, the percentage of dissolution was estimated to be $0.06 \%$. Using the same dust for a dissolution experiment conducted in MilliQ water, Guieu et al. (2002a) established a relationship between the percentage of dissolution and the concentration of dust $\left(\%\right.$ diss $\left.=-0.054 \times \ln \left[\operatorname{dust}\left(\mathrm{mg} \mathrm{L}^{-1}\right)\right]+0.32\right)$. Applying this equation to the dust concentration used in the present study, the percentage of dissolution is $0.3 \%$. The difference between these estimates could be due to the different media of dissolution. Milli-Q is more acidic than seawater and could dissolve more Fe. Despite the low percentage of dissolution of Saharan dust in seawater, the amount of Fe released $\left(0.6 \mathrm{nmol} \mathrm{L}^{-1}\right)$ was high enough to relieve the $\mathrm{Fe}$ limitation in this area. This is consistent with the results in Table 2. If Fe was not directly used by the cells because they are limited by another factor, e.g., major nutrients or light, the additional Fe could be stored. Saharan dust could therefore be a possible source of $\mathrm{Fe}$ for luxurious $\mathrm{Fe}$ storage in the northeast Atlantic Ocean.

\section{References}

Barbeau, K., E. L. Rue, K. W. Bruland, and A. Buttler. 2001. Photochemical cycling of iron in the surface ocean mediated by microbial iron(III)-binding ligands. Nature 413: 409-413.

Blain, S., P. Sedwick, B. Griffith, B. Quéguiner, M. Fiala, P. Pondaven, AND P. TRÉGuer. 2002. Quantification and modeling of the iron limitation in the subantarctic zone of the Southern Ocean. Deep-Sea Res. II 49: 3255-3275.

— AND OTHERS. 2001. A biogeochemical study of the island mass effect in the context of the iron hypothesis: Kerguelen Islands, Southern Ocean. Deep-Sea Res. I 48: 163-187.

Boyd, P. W., AND OTHERs. 2000. A mesoscale phytoplankton bloom in the polar Southern Ocean stimulated by iron fertilization. Nature 407: 695-702.

Boyé, M., A. P. Aldrich, C. M. G. VAn DEN BerG, J. T. M. DE Jong, M. Veldhuis, AND H. J. W. DE BAAR. 2003. Horizontal gradient of the chemical speciation of iron in surface waters of the northeast Atlantic Ocean. Mar. Chem. 80: 129-143.

COALE, K. H., AND OTHERS. 1996. A massive phytoplankton bloom induced by an ecosystem scale iron fertilization experiment in the equatorial Pacific Ocean. Nature 383: 495-501.

de BaAr, H. J. W., J. T. M. DE Jong, D. C. E. BAKKer, B. M. Löscher, C. Veth, U. Bathmann, and V. SMetaceK. 1995.
Importance of iron for plankton blooms and carbon dioxide drawdown in the Southern Ocean. Nature 373: 412-415.

DE Jong, J. T. M., M. Boyé, V. F. Schoemann, R. F. Nolting, AND H. J. W. DE BAAR. 2000. Shipboard techniques based on flow injection analysis for measuring dissolved $\mathrm{Fe}, \mathrm{Mn}$ and $\mathrm{Al}$ in seawater. J. Environ. Monit. 2: 496-502.

de La Rocha, C. L., D. A. Hutchins, M. A. Brzezinski, and Y. ZHANG. 2000. Effects of iron and zinc deficiency on elemental composition and silica production by diatoms. Mar. Ecol. Progr. Ser. 195: 71-79.

FALKOWSKI, P. G. 1997. Evolution of nitrogen cycle and its influence on the biological sequestration of $\mathrm{CO}_{2}$ in the ocean. Nature 387: 272-275.

Firme, F. F., D. A. Hutchins, K. W. Bruland, E. L. Rue, and D. A. WeEKS. 2003. Spatial and temporal variability in phytoplankton iron limitation along the California coast and consequences for $\mathrm{Si}, \mathrm{N}$, and $\mathrm{C}$ biogeochemistry. Global Biogeochem. Cycles 17: 1016, doi:10.1029/2001GB001824.

Gall, M. P., R. StrzepeK, M. Maldonado, and P. W. Boyd. 2001. Phytoplankton processes. Part 2: Rates of primary production and factors controlling algal growth during the Southern Ocean Iron Release Experiment (SOIREE). Deep-Sea Res. II 48: 2571-2590.

Granger, J., ANd N. M. Price. 1999. The importance of siderophores in iron nutrition of heterotrophic marine bacteria. Limnol. Oceanogr. 44: 541-555.

Guieu, C., Y. Bozec, S. Blain, C. Ridame, G. Sarthou, and N. LEBLOND. 2002a. Impact of Saharan dust inputs on dissolved iron concentrations in the Mediterranean Sea. Geophys. Res. Lett. 29: 1911-1914.

- M.-D. LoŸE-Pilot, C. Ridame, And C. Thomas. $2002 b$. Chemical characterization of the Saharan dust end-member; some biological implications for the western Mediterranean. J. Geophys. Res., 10.1029/2001JD000582.

Hutchins, D. A., AND K. W. BRUlAnd. 1998. Iron-limited diatom growth and $\mathrm{Si}: \mathrm{N}$ uptake ratios in a coastal upwelling regime. Nature 393: 561-564.

—, AND D. A., G. R. DiTullio, Y. Zhang, AND K. W. BRULAND. 1998. An iron limitation mosaic in the California upwelling regime. Limnol. Oceanogr. 43: 1037-1054.

- , V. M. Franck, M. A. BRZEZINSKI, AND K. W. Bruland. 1999a. Inducing phytoplankton iron limitation in iron-replete coastal waters with a strong chelating ligand. Limnol. Oceanogr. 44: 1009-1018.

$\longrightarrow$, AND OTHERS. 2002. Phytoplankton iron limitation in the Humbolt Current and Peru upwelling. Limnol. Oceanogr. 47: 997-1001.

Hutchins, D. A., A. E. Witter, A. Butler, And G. W. Luther III. 1999b. Competition among marine phytoplankton for different chelated iron species. Nature 400: 858-861.

Laes, A., S. Blain, P. LaAn, E. Achterberg, G. Sarthou, and H. J. W. DE BAAR. 2003. Deep dissolved iron profiles in the eastern Atlantic in relation to water masses. Geophys. Res. Lett. 30: 1902-1906.

LEBLANC, K. 2002. Variabilité spatiale et temporelle du cycle du silicium dans divers milieux oligotrophes et mésotrophes. Ph.D. thesis, Univ. de Marseille II.

, B. Quéguiner, M. Fiala, S. Blain, and J. Morvan. 2002. Biogenic silica distribution and production rate measurements using the ${ }^{32} \mathrm{Si}$ method in the Indian sector of the Subantarctic region of the Southern Ocean in summer (January-February 1999). Deep-Sea Res. II 49: 3189-3206.

LENES, J. M., AND OTHERS. 2001. Iron fertilization and Trichodesmium response on the West Florida shelf. Limnol. Oceanogr. 46: 1261-1277.

MaldonAdo, M. Y., AND N. M. Price. 1999. Utilization of iron 
bound to strong organic ligands by plankton communities in the subarctic Pacific Ocean. Deep-Sea Res. II 46: 2447-2473.

Martin, J. H. 1990. Glacial-interglacial $\mathrm{CO}_{2}$ change: The iron hypothesis. Paleoceanography 5: 1-13.

- S. E. Fitzwater, R. M. Gordon, C. N. Hunter, and S. J. TANNER. 1993. Iron, primary production and carbon-nitrogen flux studies during the JGOFS North Atlantic Bloom Experiment. Deep-Sea Res. II 40: 115-134.

Martinez, J. S., M. G. Haygood, AND A. Buttler. 2000. Identification of a natural desferioxamine siderophore produced by a marine bacterium. Limnol. Oceanogr. 46: 420-424.

Moulin, C., C. E. Lambert, F. Dulac, and U. Dayan. 1997. Control of atmospheric export of dust from North Africa by the North Atlantic Oscillation. Nature 387: 691-694.

SARthou, G., AND C. JeAnDEl. 2001. Seasonal variations of iron concentrations in the Ligurian Sea and iron budget in the Western Mediterranean Sea. Mar. Chem. 74: 115-129.

SCIANDRA, A., AND OTHERS. 1997. Growth-compensating phenomena in continuous cultures of Dunaliella tertiolecta limited simultaneously by light and nitrate. Limnol. Oceanogr. 42: $1325-1339$.

Sedwick, P. N., S. Blain, B. Quéguiner, F. B. Griffiths, M. Fiala, E. Bucciarelli, and M. Denis. 2002. Resource limitations of phytoplankton growth in the Crozet Basin, Subantarctic Southern Ocean. Deep-Sea Res. II 49: 3327-3349.

Soria-DengG, S., AND U. HorstmanN. 1995. Ferrioxamines B and E as iron sources for the marine diatom Phaedactylum tricornutum. Mar. Ecol. Prog. Ser. 127: 269-277.

Strickland, J. D. H., AND T. R. PARSON. 1972. A practical hand- book of seawater analysis. J. Fish. Res. Bd. Can. Bull. 167: 1310.

SundA, W. G., AND S. A. HunTSMAN. 1995. Iron uptake and growth limitation in oceanic and coastal phytoplankton. Mar. Chem. 50: 189-206.

, AND - 1997. Interrelated influence of iron, light and cell size on marine phytoplankton growth. Nature 390: 389392.

Timmermans, K. R., L. J. A. Gerringa, H. J. W. De BaAr, B. van Der Wagt, M. J. W. Veldhuis, J. T. M. DE Jong, AND P. L. CROOT. 2001. Growth rates of large and small Southern Ocean diatoms in relation to availability of iron in natural seawater. Limnol. Oceanogr. 46: 260-266.

Vidussi, F., H. Claustre, J. Bustillos-Guzman, C. Caillau, and J.-C. MARTY. 1996. Determination of chlorophylls and carotenoids of marine phytoplankton: Separation of chlorophyll $a$ from divinyl-chlorophyll a and zeaxanthin from lutein. J. Plankton Res. 18: 2377-2382.

, B. Manca, A. Luchetta, And J.-C. Marty. 2001. Phytoplankton pigment distribution in relation to the upper thermocline circulation in the eastern Mediterranean Sea during winter. J. Geophys. Res. 106: 939-956.

WeLLS, M. 1999. Manipulating iron availability in nearshore waters. Limnol. Oceanogr. 44: 1002-1008.

Wells, M. L., N. M. Price, and K. W. Bruland. 1994. Iron limitation and the cyanobacterium Synechococcus in equatorial Pacific waters. Limnol. Oceanogr. 39: 1481-1486.

Received: 2 December 2003

Accepted: 9 June 2004

Amended: 6 July 2004 